Canadian University Music Review

Revue de musique des universités canadiennes

\title{
Reflections in an Eastern Mirror, or Performance of a French Vaudeville in Russia
}

\section{Mary S. Woodside}

Volume 23, numéro 1-2, 2003

URI : https://id.erudit.org/iderudit/1014519ar

DOI : https://doi.org/10.7202/1014519ar

Aller au sommaire du numéro

\section{Éditeur(s)}

Canadian University Music Society / Société de musique des universités canadiennes

ISSN

0710-0353 (imprimé)

2291-2436 (numérique)

Découvrir la revue

\section{Citer cet article}

Woodside, M. S. (2003). Reflections in an Eastern Mirror, or Performance of a French Vaudeville in Russia. Canadian University Music Review / Revue de musique des universités canadiennes, 23(1-2), 84-108.

https://doi.org/10.7202/1014519ar

\section{Résumé de l'article}

Extrêmement populaires à leur époque, les vaudevilles et les opéras-vaudevilles russes du premier tiers du XIX ${ }^{\mathrm{e}}$ siècle ne se retrouvent pas dans les partitions modernes pour orchestre. Bien qu'il soit notoire qu'un bon nombre de ces comédies musicales soient tirées d'œuvres françaises, on ne connaît pas les titres originaux français, de même qu'on ignore les différences de traitement entre les numéros musicaux français et russes. En s'attardant surtout sur Babushkiny popugai [Les perroquets de grand-mère] de Pisarev (Saint-Pétersbourg, 1819), le présent article compare le vaudeville original français à son adaptation russe sous divers angles : livret, lieux de représentation et traitement musical, celui-ci s’appuyant en partie sur les sources manuscrites des partitions d'Alexeï N. Verstovski.
All Rights Reserved (C Canadian University Music Society / Société de musique des universités canadiennes, 2004
Ce document est protégé par la loi sur le droit d'auteur. L'utilisation des services d'Érudit (y compris la reproduction) est assujettie à sa politique d'utilisation que vous pouvez consulter en ligne.

https://apropos.erudit.org/fr/usagers/politique-dutilisation/ 


\title{
REFLECTIONS IN AN EASTERN MIRROR, OR PERFORMANCE OF A FRENCH VAUDEVILLE IN RUSSIA
}

\author{
Mary S. Woodside
}

A great deal of scholarly work has been published on the dispersal of French opera-comique, vaudeville and opera-vaudeville throughout Europe during the eighteenth century. ${ }^{1}$ It is the aim of the present article to continue this work into the nineteenth century for the country which is reputed to be the most Francophile of them all: Imperial Russia. As a modest beginning to this task, I have chosen a Russian vaudeville, Babushkiny popugai [Grandma's parrots] (St. Petersburg, 1819) by Alexei Nikolaevich Verstovsky (1799-1862), to show the way in which a French work was translated or adapted to the Russian stage and set to new music by a Russian composer. This single example provides a baseline for the further study of adaptations of French repertoire in Russia and helps to illuminate the world of Russian musical theatre during the early nineteenth century.

The choice of a work by Verstovsky is motivated in part by the desire to make the extensive oeuvre of this composer better known. Immediate forerunner of the "Father of Russian Music," Mikhail Glinka, Verstovsky is generally given credit for a single opera, Askoldova Mogila [Askold's Grave] (Moscow, 1835), because of its enormous popularity in Russia throughout the nineteenth century. ${ }^{2}$ Russian scholars note, however, that Verstovsky made a significant contribution to musical theatre in St. Petersburg and Moscow for almost two decades before Glinka's operas launched the Russian nationalist school on its successful career. ${ }^{3}$

Like Glinka, Verstovsky was educated in St. Petersburg. ${ }^{4}$ He graduated from the Institute of the Corps of Engineers ${ }^{5}$ about the same time that the thirteen-year-old Glinka came to the city to begin his education at the Blagorodny Pension [Boarding School for the Nobility]. Again like Glinka, Verstovsky undertook musical studies of various kinds; among his teachers

1 Among recent articles are: Brown (1992, 1997), Pendle, Pré, Haine, and Betzwieser (Vendrix 1992a).

2 See, for example, Seaman $(1991,249)$ for a general treatment of the period.

3 For a general treatment of Verstovsky's music see Keldysh (1988, 97-131).

4 I have taken biographical details from the articles on the composer from Sadie $(2001,26: 501-2)$ and Keldysh (1973, 755-57).

5 The full name of this institution was Institut Inzhenerov Putei Soobshcheniia Imperatora Aleksandra I [The Emperor Alexander I Institute of Communication Engineers]. 
were Daniel Steibelt ${ }^{6}$ and John Field, Ludwig Maurer ${ }^{7}$ and Karl Zeuner (two of them, Field and Zeuner, also teachers of Glinka for a brief period). Because of the connection of Steibelt and Maurer with the Imperial Theatres, Verstovsky was soon composing new music for fashionable vaudevilles recently imported from Paris. His first success, Babushkiny popugai, an opéra-vaudeville in one act, was followed by more than forty works for musical theatre in this and related sub-genres.

In 1823 Verstovsky moved to Moscow and in 1825 became the director of the newly opened Bolshoi Theatre. Later he was appointed inspector of theatres for the whole city. He remained the most powerful civic musical administrator in Moscow until his retirement in 1860. During this time a steady output of vaudevilles and operas allowed Verstovsky to consider himself the true father of Russian music. ${ }^{8}$

Of the many operas and lighter works written by Verstovsky, only the opera Askoldova Mogila and the vaudeville Kto Brat, Kto Sestra [Which the Brother, Which the Sister] (St. Petersburg and Moscow, 1824) are readily available today (Verstovsky 1949, 1963). Although a few anthologies present excerpts, they rarely give information regarding sources or the extent of the material that is sampled. For this reason, I have used manuscript sources in Moscow archives to clarify questions concerning Verstovsky's musical contribution to the vaudevilles discussed here. ${ }^{9}$

The history of the vaudeville began in France, where theatrical presentations in the public fairs included the singing of rhyming quatrains to the tunes of popular songs. These musical numbers were interspersed in comedies with spoken dialogue, often presenting parodies of more serious works. By the nineteenth century the character of the comedies had turned to social satire but

6Daniel Steibelt (1765-1823) was German-born but led a career of composer and piano virtuoso in Paris, London and St. Petersburg. According to Keldysh (1988), he first visited St. Petersburg in 1809, was named maitre de chapelle of the Court French troupe in 1810 and of the French opera in 1811. Russian performances of his operas included: Romeo i Iuliia, given in Russian translation in Moscow, 1808; La princesse de Babylon (St. Petersburg, French troupe, 1808); Cendrillon (St. Petersburg, Hermitage Theatre, French troupe, 1810). The latter two operas were given repeatedly and a ballet, Cendrillon, possibly using Steibelt's music, was also very popular. Keldysh does not list Steibelt's Sargines-but does mention operas of the same name by Dalayrac (Moscow, Arbat Theatre, 1810) and Paer (St. Petersburg, German Troupe, 1815). From 1812 until 1819 there was no French troupe in St. Petersburg and Steibelt's music was most often used in combination with that of Cavos and other composers for ballets.

7Ludwig Maurer (1789-1878) was a violinist and composer who first arrived in St. Petersburg in 1807. He contributed music to opera, vaudeville and ballet in St. Petersburg and Moscow. Keldysh (1988) mentions an opera, Les dangers de l'indiscrétion (Moscow, 1812) given by a French troupe at the Arbat Theatre but Maurer is more commonly associated with vaudeville; the first of his vaudevilles was performed in 1818 at the St. Petersburg Bolshoi theatre and he frequently collaborated with other composers, including Verstovsky, in both St. Petersburg and Moscow. His Der neue Paris (Riabov, 1822) was published in piano/vocal score in 1826; it was performed in Moscow and St. Petersburg as Novii Paris in 1829 with additional music by Verstovsky.

8Richard Taruskin (1997, 41-42) translates Verstovsky's bitter "review" of Glinka's first opera: “... I wish you'd listen again to the third act finale of Askold's Grave. It would shame you and convince you that the Dawn of Russian Music broke for opera in Moscow, not Petersburg. I am the first to idolize Glinka's marvelous talent, but I will not and cannot renounce my rights to primacy ..."

9I am preparing a thematic catalogue of Verstovsky sources in Moscow. 
the song texts in printed librettos were still headed by an indication of the timbre, the title of the tune to which the words were to be sung. By that time, the unaccompanied tunes had been collected into an enormous anthology by Pierre Capelle (1816), the famous La clé du Caveau and scores and parts for some individual vaudevilles were made available (though not published). Innumerable vaudevilles were written during the late eighteenth and early nineteenth century by French playwrights, librettists and vaudevillistes such as Scribe (1791-1861), Théaulon de Lambert (1787-1841), Mélesville (17871865), Duvert (1795-1876) and Dupaty (1775-1851), ${ }^{10}$ to mention only a few whose works were transported to Russia. Some plots go back to older works by more famous librettists such as Sedaine and Favart, some even to Molière.

A comparison of a vaudeville in Russian translation with its French original is interesting both in the new and the old context. Here we will examine the work mentioned above, Babushkiny popugai. First performed at the St. Petersburg Bolshoi on July 28, 1819 (old style) at a benefit for Ivan Ivanovich Sosnitsky and Elena Iakovlevna Sosnitskaia, ${ }^{11}$ it was later given in Moscow at the "Theatre on the Makhovoi"12 on May 25, 1821. Although there is often some discrepancy in the labeling of particular works from one Russian source or reference work to another, this example is consistently labeled an operavodevil in one act. Allowing for some inconsistency in Russian terminology, this implies the inclusion of more musical numbers than in the Russian komediia-vodevil or plain vodevil, both of which typically contained only one or two musical items. The Russian terminology does not indicate, however, that there is a greater preponderance of music in the Russian adaptation than there was in the French source, a vaudeville en un acte; in fact, there is a reduction in the number of musical items in the adaptation. As in so many areas of comparison between cultures, the terminology of genre can be misleading.

The original French work, Les perroquets de la mère Philippe, was written by Armand and Achille d'Artois and Marie-Emmanuel Théaulon de Lambert, ${ }^{13}$

10 According to the Dictionnaire des littératures de langue française (1994), by the mid-nineteenth century there were estimated to be 168 vaudevillistes and, by the end of the century, more than 10,000 plays of this type. Many of these were collaborative efforts: Mélesville (pseudonym for Joseph-Anne-Honoré Duveyrier), for example, wrote some 300 works either alone or together with Scribe, Pixérécourt, Bayard, Merle, Carmouche, Théaulon, and Dumersan. Biographies of these authors, who came from all classes of French society, and lists of their works are included in the previously-mentioned Dictionnaire, the Italian Enciclopedia dello spettacolo (Roma: Sansoni, 1962) and the Archives biographiques françaises (so far incomplete). Many of them belonged to singing societies in Paris, a contemporary description of which can be found in Brazier (1969).

11 I. I. Sosnitsky (1794-1871) delighted audiences in spoken comedies and vaudevilles by Shakhovskoi, Khmelnitsky and Zagoskin from 1811 until his death. He also played leading roles in non-Russian plays such as Molière's Tartuffe and Beaumarchais's Le mariage de Figaro. His wife, E. Ia. Sosnitskaia (1799-1855), was a dramatic actress and singer, who played leading roles in Cavos's Ivan Susanin and Mozart's Volshebnoifleite [The Magic Flute]; after 1821 she also joined her husband in comedies and vaudevilles.

12Before the opening of the Moscow Malyi and Bolshoi Theatres in 1824 and 1825 respectively, operas and vaudevilles were presented at various venues, including a theatre referred to variously as the "dom Pashkova," "Teatr Pashkova," or, owing to its location, the "Teatr na Mokhovoi [Theatre on Mokhovoi Street]." The Moscow première is listed in Bernandt (1962) but not in Keldysh (1986).

13 Achille d'Artois de Bournonville (1791-1868) and his brother François-Victor-Armand (17881867) collaborated on many works, often with their brother Theodore or another writer. In 1830 Armand 
first performed in Paris at the Théâtre des Variétés in 1818 and published by J.-N. Barba in the same year. It was still in the active repertoire at the Variétés in 1826, so the Russian performances can be regarded as more or less simultaneous with the Parisian ones. There is no indication of the availability of music in the printed libretto ${ }^{14}$ and so far I have found none in French libraries, so in this case the reason for Verstovsky's new music was apparently the unavailability of the original score or parts.

Keldysh (1986 4:382) describes this Russian opera-vodevil as being "freely translated from the original French." This description is accurate for a number of reasons. The character names in Khmelnitsky's translation do not always match those of the original. La mère Philippe becomes Gospozha Kurmond but her niece Mme de Merville retains her original name. Lucile, Merville's daughter, becomes Tereza, and Nicette, a young peasant, becomes the young serf girl Zhorzheta [Georgette]. Dermont, ${ }^{15}$ described as a former "militaire," becomes the Russian, Zherkur, and his nephew Saint-Leon, "Capitaine de Dragons" is changed to Florvil, "Ofitser." Finally, Jaquot, "paysan normand" remains Zhako, "young serf."

The story concerns two young girls, kept from knowing of the very existence of young men by La mère Philippe/G-zha Kurmond because of her own unhappy experience with matrimony. They finally meet and marry the two "creatures" described by their elders as "large parrots" (to explain their ability to talk.) The fun involves the girls' bird-shooting expedition which is saved from disaster only by their mercy for their prey because they look so happy. They later can enjoy teaching the "parrots" to repeat their jokingly amorous phrases.

The original story is told in eighteen scenes with the aid of thirty-one vaudevilles; the timbres are indicated for all but two, one of which has new music provided by a "M. Tourterelle." 16 The Russian counterpart has seventeen scenes and only nineteen couplets; there is no indication of music in the libretto since this was newly composed by Verstovsky. The Russian version has been shortened by one scene and several couplets, including any that involve the use of chorus, as in the vaudeville finale. This last number has been replaced by new text in the published libretto, although in Verstovsky's manuscript score the text resembles the original French. Also, the characters singing this last number have been reduced from 5 to 4 , and include the gentry couple, Florvil and Tereza, rather than the peasant one, Nicette and Jaquot. See table 1 for a brief synopsis of the scenes in Les perroquets de la mère Philippe and a listing of the corresponding Russian scenes and musical numbers. Changes made in the Russian piece, which follows the French very closely, are indicated in italics.

took over the direction of the Thêatre des Variétés, which he used as a forum for his political views. Théaulon wrote some 250-300 theatre works, including both vaudevilles and opéras-comiques, either alone or in collaboration with other authors. All three authors of Les perroquets are indicated in the catalogue of the Bibliotheque nationale but the title page of the Barba edition indicates the third author only as ***.

14 In some librettos there is an indication placed beneath the list of personnages and acteurs that music is available, often through the maitre de musique of the theatre.

15 In the libretto this character is mis-spelled "Germont" in the initial list of personnages.

$16 I$ am grateful to an anonymous reviewer of this article for identifying $M$. Tourterelle as a member of a musical family in Paris who worked as a rehearsal pianist for the Opéra-Comique. 
Table 1. Comparison of French and Russian versions of Les perroquets de la mère Philippe

La mère Philippe (P.) = Gospozha Kurmond (K.)

Madame de Merville (M.) = Gospozha Mervil (M.)

Lucile (L.) $=$ Tereza (T.)

Nicette (N.) = Zhorzhetta (Zho.)

Dermont (D.) = Zherkur (Zhe.)

Saint-Léon (S-L.) = Florvil (F.)

Jaquot (J.) = Zhako (Zha.)

Note: Dermont is listed as "Germont" in the list of Personnages in the Paris, 1818 libretto.

\begin{tabular}{|c|c|}
\hline $\begin{array}{l}\text { Scene 1: P. \& M. The latter hears about } \\
\text { old flame (D.) who wants her to come } \\
\text { back to Paris. } \\
\text { Nos. } 1^{*}, 2^{*}, 3,4^{*}:{ }^{17}\end{array}$ & $\begin{array}{l}\text { K. \& M. } \\
\text { Nos. 1-4: couplets for } K \text {. }\end{array}$ \\
\hline $\begin{array}{l}\text { Scene 2: The same \& D., S-L., J. The } \\
3 \text { men are hidden in } 3 \text { trees while the } \\
\text { women agree again about men. } \\
\text { No. 5: duo for P. \& M. }\end{array}$ & $\begin{array}{l}\text { The same \& Zhe., F., Zha. } \\
\text { No. 5: duo for K. \& M. }\end{array}$ \\
\hline $\begin{array}{l}\text { Scene 3: The } 3 \text { men. They discuss the } \\
\text { situation with the } 2 \text { girls who don't } \\
\text { know that men exist. } \\
\text { The girls appear with guns; the men } \\
\text { hide. } \\
\text { No. } 6 \text { : trio for D., S-L., J.; no. } 7^{*} \text { : trio } \\
\& \text { chorus. }\end{array}$ & $\begin{array}{l}\text { The } 3 \text { men. } \\
\text { No. 6: trio for Zhe., F., Zha. } \\
\text { Trio \& chorus omitted. }\end{array}$ \\
\hline $\begin{array}{l}\text { Scene 4: L., N., S-L. The two girls are } \\
\text { dressed for the hunt. The girls talk of } \\
\text { how little they know; S-L. is hiding } \\
\text { comments on his desire to instruct } \\
\text { them; they speak of shooting birds. } \\
\text { Then they see the men, thinking they } \\
\text { are birds. The girls run away. } \\
\text { No. 8: duo for L. \& N.; no. 9*: duo for } \\
\text { L. \& N.; no. } 10^{*}: \text { duo for L. \& N. with } \\
\text { interjections by S-L. }\end{array}$ & $\begin{array}{l}\text { T., Zho., F. } \\
\text { No. 7: duo for T. \& Zho. }=\text { no. } 8 \text { in Fr. } \\
\text { No. 8: duo for T. \& Zho. = no. } 9 \text { in Fr. } \\
\text { No. 9: duo for T. \& Zho., interjections } \\
\text { by F. = no. } 10 \text { in Fr. } \\
\text { Russian source lists as no. } 10 \text { the same } \\
\text { tune as no. } 9 \text {, for stanza added after } \\
\text { spoken dialogue. }\end{array}$ \\
\hline
\end{tabular}

17 Numbering of musical items follows the French and Russian librettos. Incipits of all Russian melodies are found in appendix 1. Incipits of French melodies provided in appendix 2 are marked with an asterisk. 


\begin{tabular}{|c|c|}
\hline $\begin{array}{l}\text { Scene 5: } 3 \text { men. They discuss the } \\
\text { "Dragon," M., P. } \\
\text { No. 11*: duo for S-L. \& D.; no. 12*: } \\
\text { duo for S-L. \& D. }\end{array}$ & $\begin{array}{l}3 \text { men. } \\
\text { No. } 11 \text { : Solo for } F . \text { Russian source } \\
\text { lists as no. } 12 \text { the same tune as for } \\
\text { no. } 11 \text {, for stanza added after spoken } \\
\text { dialogue. } \\
\text { No. } 12 \text { in Fr. version omitted. }\end{array}$ \\
\hline $\begin{array}{l}\text { Scene 6: P., L., N., J. in tree. } \\
\text { P. explains that the creatures are } \\
\text { parrots-the idea coming from the } \\
\text { tune titled "A Girl Is a Bird." P. } \\
\text { recognizes J., talks to him, prepares to } \\
\text { shoot him, he runs. } \\
\text { No. } 13^{*} \text { : P; no. } 14^{*} \text { : P. }\end{array}$ & $\begin{array}{l}\text { K., T., Zho., Zha. in tree. } \\
\text { No. } 13: \mathrm{K} . \\
\text { No. } 14 \text { in Fr. version omitted. }\end{array}$ \\
\hline $\begin{array}{l}\text { Scene 7: P., L., N. } \\
\text { L. tells P. about seeing another } \\
\text { "Parrot" who called out "l'amour." } \\
\text { P. explains that parrots are bad but N. } \\
\text { \& L. would like to trap one. } \\
\text { No. 15*: L.; no. 16: trio for P., N., L. }\end{array}$ & $\begin{array}{l}\text { K., T., Zho. } \\
\text { No. } 14: \mathrm{T} .=\text { no. } 15 \text { in Fr. version. } \\
\text { No. } 16 \text { in Fr. version omitted. }\end{array}$ \\
\hline $\begin{array}{l}\text { Scene 8: } 3 \text { men. J. tells them that P. } \\
\text { told the girls they were parrots. M. } \\
\text { approaches, J. and S-L. leave, D. stays. } \\
\text { No. 17: trio for J., S-L., D. }\end{array}$ & $\begin{array}{l}\text { Scene abbreviated. } \\
\text { No. } 17 \text { in Fr. version omitted. }\end{array}$ \\
\hline $\begin{array}{l}\text { Scene 9: D., M. } \\
\text { D. wishes to marry M. } \\
\text { Nos. 18*, 19*, 20: D.; no. 21: duo for } \\
\text { M. \& D. }\end{array}$ & $\begin{array}{l}\text { Nos. } 18-20 \text { in Fr. version omitted. } \\
\text { No. } 21 \text { appears as a single quatrain } \\
\text { for M., with no separate tune supplied. }\end{array}$ \\
\hline $\begin{array}{l}\text { Scene 10: N. \& L. The girls are } \\
\text { looking for the parrots. N. runs out, } \\
\text { followed by J.; S-L. approaches L. } \\
\text { No. } 22^{*} \text { : duo for L. \& N. }\end{array}$ & $\begin{array}{l}\text { No. } 15 \text { : duo for T. \& Zho. }=\text { no. } 22 \text { in } \\
\text { Fr. version. }\end{array}$ \\
\hline $\begin{array}{l}\text { Scene 11: [mistakenly numbered } 12 \text { in } \\
\text { libretto] L., S-L. They talk, L. } \\
\text { thinking she is talking to a parrot. He } \\
\text { tells her that she is made for him. P. } \\
\text { calls from a distance. } \\
\text { No. } 23^{*} \text { : duo for S-L. \& L.; no. } 24: \\
\text { duo (new music by M. Tourterelle) in } \\
\text { which L. teaches S-L. to talk. No. } 25: \\
\text { duo for S-L. \& L. }\end{array}$ & $\begin{array}{l}\text { No. 16: duo for F. \& T. = no. } 23 \text { in Fr. } \\
\text { version. } \\
\text { No. 17: duo for F. \& T. = no. } 24 \text { in Fr. } \\
\text { version. } \\
\text { No. } 25 \text { in Fr. version omitted. }\end{array}$ \\
\hline
\end{tabular}




\begin{tabular}{|l|l|}
\hline $\begin{array}{l}\text { Scene 12: L., P., later N. } \\
\text { The girls tell P. they are looking for } \\
\text { parrots. } \\
\text { No. 26*: trio for L., P., N. }\end{array}$ & No. 26 in Fr. version omitted. \\
\hline $\begin{array}{l}\text { Scene 13: P., then D. She doesn't see } \\
\text { him, he throws a letter at her feet } \\
\text { which she reads. She realizes M. is } \\
\text { calling her a fool behind her back and } \\
\text { planning a rendezvous with D. She } \\
\text { plans to interrupt them. } \\
\text { N.27*: P. }\end{array}$ & No. 27 in Fr. version omitted. \\
\hline $\begin{array}{l}\text { Scene 14: Lucile. She enters with a } \\
\text { basket of fruit, singing. } \\
\text { No. 28: L.-no timbre indicated. }\end{array}$ & No. 18: T. = no. 28 in Fr. version. \\
\hline $\begin{array}{l}\text { Scene 15: L., N. } \\
\text { N. enters with basket of fruit, singing } \\
\text { same tune as in scene 14. }\end{array}$ & No. 18: N; same tune as in scene 14. \\
\hline $\begin{array}{l}\text { Scene 16: L., N., M. trio to same tune, } \\
\text { no. 28 }\end{array}$ & $\begin{array}{l}\text { T., Zho., M., F., Zhe., Zha. Russian } \\
\text { version includes scene 17 in scene } 16 . \\
\text { No. 18: trio for T., Zho., M. Same } \\
\text { tune as in scene 14. }\end{array}$ \\
\hline $\begin{array}{l}\text { Scene 17: Same 3 women, 3 men. } \\
\text { They all sing same tune, no. 28. They } \\
\text { all decide to get married. } \\
\text { No. 29*: quartet for M., L., D., N. } \\
\text { same tune as no. 22. } \\
\text { No. 30: quintet for M., D., L., S-L., N. }\end{array}$ & $\begin{array}{l}\text { Material incorporated into scene 16. } \\
\text { Nos. 29 \& 30 omitted. }\end{array}$ \\
\hline $\begin{array}{l}\text { Scene 18: All } 6 \text { \& P. The girls tell P. } \\
\text { they have trapped some parrots. She is } \\
\text { angry, S-L. tells L. that they are men, } \\
\text { not parrots. P. agrees they should all } \\
\text { marry. } \\
\text { No. 31*: duo for L. \& S-L. } \\
\text { No. 32*: vaudeville finale with } \\
\text { chorus. Stanzas for P., D., N., J., P. } \\
\text { again, L. separated by choral refrains. } \\
\text { L.'s final stanza addressed to public }\end{array}$ & $\begin{array}{l}\text { No. } 19: \text { in } \text { Fr. versian libretto has only } 4 \\
\text { stanzas for K., F., Zho. \& T., no } \\
\text { choral refrains. Text differs from both } \\
\text { Russian music MS source and French } \\
\text { libretto. }\end{array}$ \\
\hline
\end{tabular}

The principle behind changes to the Russian vaudeville appears to be the desire to shorten the performance time of the vaudeville; the omission of musical items, especially those where the repetition of a choral refrain would double the performance time of a musical item, would accomplish this. The spoken portion of the play remains much the same, so the basic structure of the comedy would survive. Changes to the text include a slight abbreviation to 
scene eight and the collapse of scenes sixteen and seventeen into one, apparently because the two ensembles (nos. 29 and 30 ) of the original scene seventeen have been omitted and the one remaining musical number in that scene (no. 28) uses the same melody and some repetitions of text as in the previous three scenes.

The treatment of the text of the couplets could also be characterized as 'free translation.' The first set of couplets, for which the French and Russian texts and their English translations appear below, serves as an example: the general meaning of the French text is maintained and the translator has also kept the original rhyme scheme. Also typical of many of the settings of couplets in this vaudeville is the choice of a timbre, which translates as "Lisa marries the handsome Gernance," whose title expresses an appropriate sentiment for the plot. ${ }^{18}$ This layer of meaning would be lost in the Russian performance since it would have no counterpart in Verstovsky's newly-composed music. Later vaudevilles by the same composer often set new lyrics to his own previously-used tunes, and could thus potentially re-introduce this level of meaning. Verstovsky's melodies themselves can present an element of humour, as when Tereza teaches the "parrot" to speak using detached notes to imitate her manner of "baby-talk" (appendix 1, no. 17). The way in which the orchestral part also could provide humour by extra-textual allusions is discussed below.

La mère Philippe to her niece, Mme De Merville, who has indicated her desire to leave their country retreat and return to the city (to the tune of "Lise épouse l'beau Gernance" [Lisa marries the handsome Gernance]) ${ }^{19}$

La mère Philippe:

Quittant ce séjour tranquille, Quoi! Vous pourriez, à la ville,

Revoir un sexe trompeur

Qui fit tout notre malheur?

Ah! Trop faibles que nous sommes!

Quoi! Vous n'avez pas déjà

Oublié qu'il est des hommes? ${ }^{20}$

Mme De Merville:

Peut-on oublier cela?

G-zha Kurmond:

Naskucha mirnoi tishinoiu,

Neuzhli v gorode tolpoiu
Mother Philippe:

Leaving this quiet place, What! In the city you might

See again the deceitful sex

That caused all our trouble?

Ah! How weak we are!

What! Have you not already

Forgotten that men exist?

Madame de Merville:

Could one forget that?

Madame Kurmond:

Bored by this peacefulness, Maybe in the city crowd

18Several of the timbres in Les perroquets relate to nature (appendix 2, nos. 1, 2, 7, 13, 19). In one case, the title of timbre would seem to be the origin of the character's own thought processes: La merre Philippe has to think quickly how to explain the existence of the three men her young charges have met and comes up with the idea that they are parrots; her couplets are set to the timbre "Une fille est un oiseau."

19For the most part the translations from French and Russian to English are my own. However, I would like to thank Dr. Neal Johnson and Elena Zagorodnaia for their valuable advice, particularly on colloquialisms. Any errors which remain are my own.

20According to Robert (1981, 710), the expression "il est" is a literary usage for "il y a" and this line, which may seem ambiguous, translates as "men (do) exist," literally "there are men." 
Reshishsia videt ty muzhchin?

Ia zla na nikh ne be prichin,

I povtoriu $v$ moem sovete:

Iz myslei dolzhno istrebit,

Chto est eshche muzhchiny v svete.

G-zha Mervil:

Kak mozhno eto pozabyt?

(Khmelnitskii 1849, 2:331-32)
You will decide to see men?

I resent them with good reason

And repeat my advice:

You must forget

That men still exist in the world.

Madame Mervil:

How could anyone forget that?

A meaningful comparison of melodic styles of the French and Russian vaudeville would have to take into account the great variety involved in both the French (La clé) and Russian (Verstovsky's forty or so works in this genre) vaudeville repertory. Still, preliminary observations can be made by comparing the melodic style of Verstovsky tunes for Babushkiny popugai with a number of the French timbres indicated in the libretto of Les perroquets de la mère Philippe (see appendix 1 for the incipits of all musical items by Verstovsky, and appendix 2 for a selection of incipits of melodies from La clé du Caveau). Some of the French melodies are for numbers omitted in the Russian play.

It is conceivable that Verstovsky had access to a copy of the French anthology as well as the printed libretto indicating which timbres had been used. Conceivable too that he tried to use a similar melodic style in setting his Russian couplets. The frequent use of repeated notes, dotted rhythms, triadic outlines, upbeats (especially involving a rising perfect fourth or a sixth) and turning note figures are common to both French and Russian melodies. Both would be adjusted to new texts in syllabic style.

An example of one complete number in its French and Russian versions shows other similarities but some interesting differences: examples 1 and 2 present the second number in the vaudeville, "Je n'avais que dix-sept ans" [I was only seventeen] / "V piatnadtsat let, moi milyi drug" [At fifteen years, my dear friend]. ${ }^{21}$ The French timbre, "Vaudeville de la belle fermière," [Vaudeville of the pretty farm wife] taken from La clé du Caveau, second edition, fits the words well, with a few changes of slurs (marked by square brackets in the example 1 and a repetition of the final line of text. The Russian translation, which drops the age of the bride by two years and makes the first husband even more undesirable, is set in similar fashion: mainly syllabic text-setting; the first

21 Translations of the French and Russian texts are as follows:

Je n'avais que dix-sept ans, / Un époux désola ma vie; / Je fus veuve en peu de temps, / D'un second je fis la folie; / Avec lui, Dieu! quel tourment! / Je fus veuve heureusement, / Et je jurais bien franchement en perdant le troisième / De n'en pas prendre un quatrième.

I was but seventeen / When a husband desolated my life / I was soon a widow / I made the mistake of taking a second / With him, God! what a torment / Happily I was a widow again / And I swore once and for all on losing the third one / To never take a fourth.

V piatnadtsat let / moi milyi drug/ Imela muzha ia prezlogo / No tolko umer moi suprug / ia totchas vyshla za drugogo. I s'etim ne bylo utekh / On takzhe umer no na grekh / moi tretii muzh byl khuzhe vsekh, moi tretii muzh byl khuzhe vsekh / Teper reshilas ia byt tverdoi / i mne ne nuzhen muzh chetvertyi.

At fifteen years, my dear friend, / I had a contemptible husband / But when my husband died / I soon took another / With him also there was no joy / He too died but as bad luck would have it / My third husband was worst of all / Now I've decided to be steadfast / And I don't need a fourth husband. 


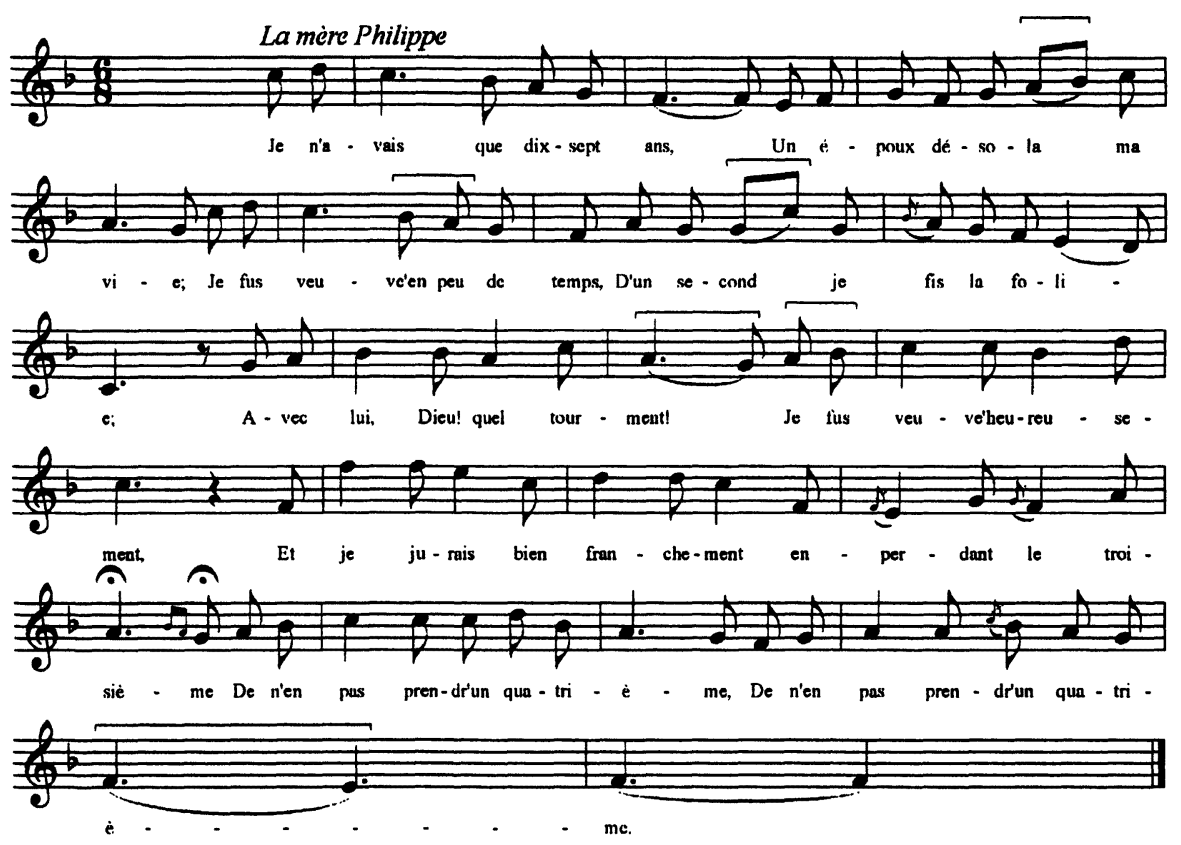

Example 1: "Je n'avais que dix-sept ans" from Théaulon et Arm. \& Ach. d'Artois (1818) to the timbre "Vaudeville de la belle fermière" (Capelle 1816). Example arranged by the author; square brackets indicate editorial changes to slurs to accommodate the new text.

two phrases similar but with open and closed cadences, and the second one modulating to either the dominant or the relative major; a dramatic pause (or two) toward the end; a repeated final line. Still, the Russian tune is in the minor (with the turn to the relative major at bars 10-13), its common time in contrast to the lilting compound metre of the French tune. The five regular phrases of the French song become six in the Russian, whose fifth phrase (bars 14-17), presents a more dramatic than lyrical line leading up to the high " $a$ " of the repeated final line of text. This music seems to be rather operatic in character and also appears to be designed to set a particular text, unlike the French situation (although Verstovsky often re-used his melodies to set new text in later vaudevilles, as far as I know none of the tunes in Babushkiny popugai were re-cycled in this way.)

There seem to be a number of reasons for omitting specific musical numbers from the Russian version of Les perroquets. First, a number may not seem particularly necessary to the plot. In scene 3 , for example, the second of two trios (no. 7) expresses similar ideas to the first. The three men have been discussing the young girls who, they have just learned, don't know that men even exist. In the first trio in the scene, no. 6, "Il faut pour déjouer ces trames [One must in order to thwart their plot]," Dermont asks in the first stanza: "Must we put up with the fact that women don't know we exist?" In the second 

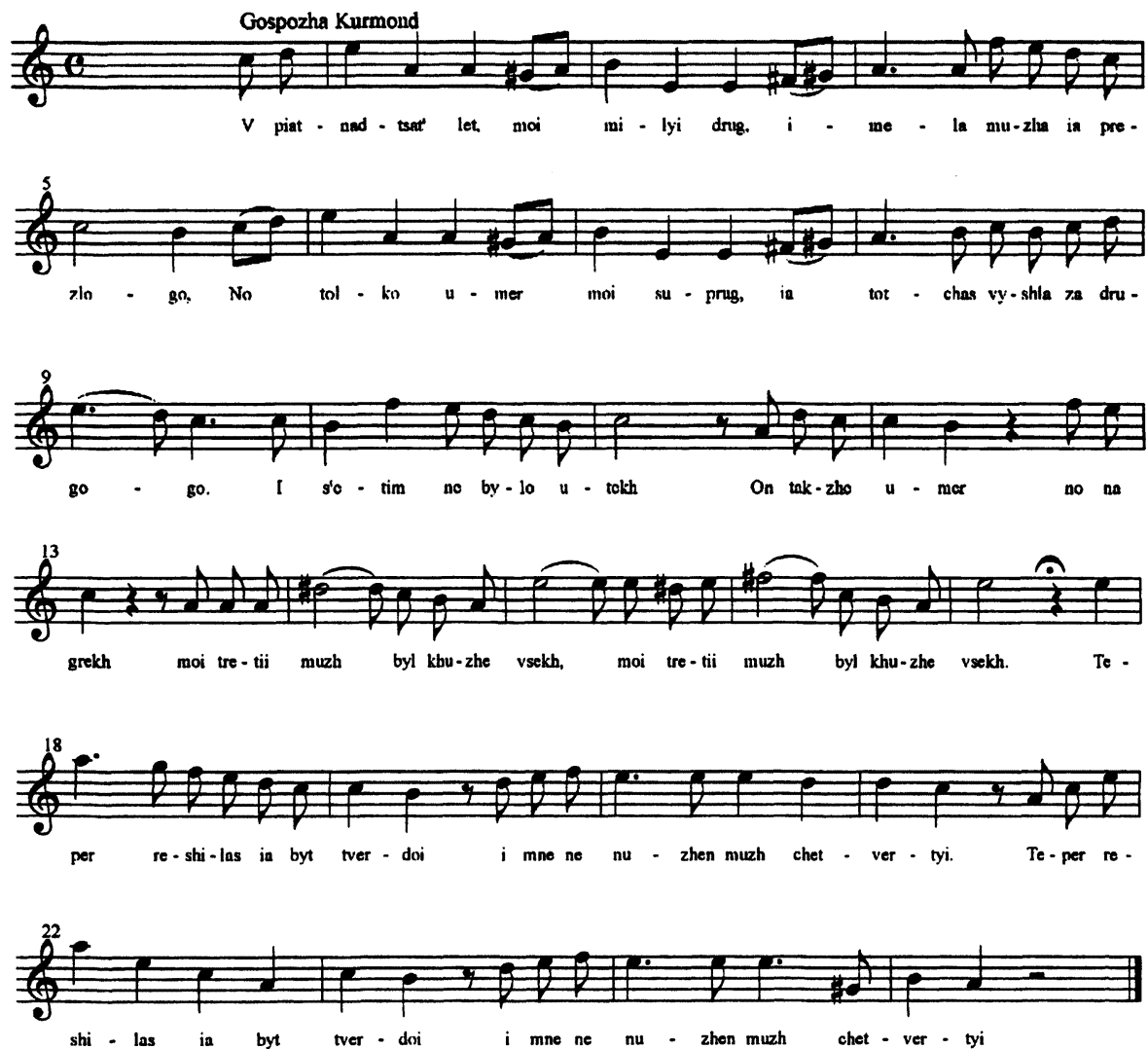

Example 2: "V piatnadtsat' let" [At fifteen years] from Verstovsky, Babushkiny popugai [Grandma's Parrots]; this example is arranged by the author using text from Khmel'nitskii (1849) and melody from Voinova $(1971,9)$.

one, Saint-Léon, the vain one, says: "Ah, what pleasure to offer myself to their eyes" and Jaquot, in his, adds: "We can be sure that they have never seen such handsome men." 22 The men then see reality: the girls themselves are coming into the garden, guns under their arms. The men quickly and wisely decide to hide in the trees. In the following trio with chorus, Jaquot asks: "Do you think we will be able to get them used to seeing us?" Dermont responds "Women get used to seeing men very easily." The chorus then repeats the refrain (which is the same as the text of the Saint-Léon's first stanza): "Toward this woods / I can see / Every woman who approaches." ${ }^{23}$ This trio may have been thought

22 The exchange runs as follows: Dermont: "Devons-nous souffrir que les femmes / Ignorent que nous existons?" Saint-Léon's stanza responds: "Ah! Quel plaisir / À leurs yeux de m'offrir" and Jaquot, in his, adds: "Nous sommes bien sûr' qu'ell's n'auront / Jamais vu d'si beaux hommes."

23 Jaquot: “... Croyez-vous, ... qu'nous aurons l'pouvoir / D'les accoutumer à nous voir?” Dermont: “À voir les hommes ... Femme s'accoutume aisément." Saint-Léon, repeated as choral refrain: "Vers ce bois / D'ici je vois / Chacune qui s'avance ..." 
superfluous, or even anti-climactic; eliminating it would also serve another end, the excision of the chorus.

Cutting out choral participation in scene three is echoed in the vaudeville finale, where it serves as one way to shorten a lengthy musical number. The number of stanzas is reduced from six of eight verses to four stanzas of four, and the choral refrains following each stanza are simply dropped. Some of the sentiments expressed by the French characters are omitted. For example, Lucile's final address to the public asks them to take note, among other things, of the authors of this little play, who will entertain them again whenever they are pleased to return to this theatre. Her Russian counterpart, Tereza, also has the last word, but it refers to the story just told rather than addressing the audience.

The choice of which characters to include in the Russian vaudeville would seem to hinge on both dramatic and practical grounds. Jaquot is replaced by Florvil, perhaps because the sentiments expressed in his stanza strike a discordant note. ${ }^{24}$ In addition, Florvil is a more important musical figure in the vaudeville and was no doubt played by Sosnitsky; he participates in five musical numbers in the Russian vaudeville, to Zhako's one trio and no solos or duos. The three female characters included in the Russian finale have even more important parts, musically speaking: Tereza, played by Sosnitskaia, takes part in ten numbers, including three solos, six duos and one trio; G-zha Kurmond has six solos and one duo; Zhorzheta, two solos, three duos and one trio.

Naturally all of the characters have fewer numbers in the Russian version of the vaudeville than the French, but in general their relative importance (from a musical point of view) remains the same. Neither Mme de Merville nor Jaquot, for example, were given much music even in the original work. Dermont is the exception, his singing part being practically eliminated in the Russian version. Scaled down from a total of ten numbers, including three solos, one duo, and three trios, Dermont is left in only one trio, even his scene nine duo with Mme de Merville being turned into a solo for her. Although the spoken text for Dermont remains much the same, the omission of his solo numbers (usually relating to his desire to marry Mme de Merville) represents a musical excision of that subplot, and most of the musical contribution of that performer. The result is that the two Sosnitsky's would dominate the spotlight, as would befit their benefit performance.

A noticeable difference between the French and Russian versions of Perroquets is the mode of address used by the various characters and their various exclamations. In the French play the only character who swears much is Nicette, the peasant girl, who utters the occasional "Dam!" [from Notre Dame] or "Mon Dieu!" [My God!]. Also indicating her peasant status, she addresses Lucile as "Mam'zelle" while Lucile calls her by her own name... and never swears. Jaquot, the other peasant character, also says "Diantre" [Dam! softened form for Devil] or "Que diable" [what the Devil] but respectfully addresses

24Lisette doesn't know how to say anything, / Except to repeat "I love you tenderly." / Young Lucas, in his delirious state / Marries this charming parrot. / But the next day he will cry, / On hearing her cackle / Well, I have a magpie / Instead of a parrot! 
Nicette as "Mam'zelle." Of the upper-class characters only Dermont lets out the occasional "Corbleu," "Morbleu," "Parbleu," ["bleu" a replacement for "Dieu"] or "Diantre!" La mère Philippe only once lets slip a "Mon Dieu!" or a mild "Miséricorde" [Mercy]. The Russians, in contrast, all use similar language, and are much more apt to invoke the deity without euphemism: "Akh! Bozhe moi" [O! My God] and "Radi Boga" [For God's sake or For Goodness Sake]. They also refer to each other affectionately much more often, naming the person they speak to in the familiar "Tetushka" [Auntie], "Diadiushka" [Little Uncle], "Matushka" or "Maminka" [Little Mother or Mummy], Babushka [Grandma], or "moi milyia" [my dear]..$^{25}$ The French "ma tante" or "mon neveu" sounds formal by comparison; only once does Lucile call Mme Philippe "ma chère tante." Nonetheless, Zhorzheta follows her French model in addressing Tereza respectfully as "sudarynia" [madam or ma'am].

Because we lack the orchestral setting of Les perroquets de la mère Philippe, the orchestration of Babushkiny popugai is of particular interest. In an article on the orchestra and chorus at the Paris Comédie-Italienne in the second half of the eighteenth century David Charlton $(1985,91)$ notes: "Of the performance of popular vaudevilles we still know little; but there is evidence for a reduced size of orchestra on the two days [per week] when such entertainments were given, with a total of six violins (13 January 1782)." A hint regarding the other instruments used comes from a document of 1788, which mentions "violins ... cellos (basses) and wind instruments" but, as Charlton remarks $(1985,92)$, "all these need not have played all through ..."

The musical performance of popular vaudevilles in France is indeed a topic which has not been explored, and many of the sources which can be marshalled for the larger genres (Charlton uses the registres or record books for the Comédie-Italienne and the annual theatre guides, Les spectacles de Paris) do not give the necessary details concerning vaudevilles. La clé $d u$ Caveau, so useful for timbres, does not, of course, indicate orchestration. The St. Petersburg version of Les perroquets de la mère Philippe may be an indicator of the orchestral practice of the Paris original, although one must not forget the Russian predilection for lavish operatic performances still in evidence today.

Verstovsky sets the first number in the vaudeville (its single stanza of text is translated above) to a newly-composed tune with accompaniment of two horns in D, two flutes, two clarinets in A, two bassoons, and strings (violins I and II, viola, basso). ${ }^{26}$ Only this and the final number have eight woodwinds (if we may consider the horns as woodwinds here); all but one of the rest of the numbers have only six, the remaining one only five (table 2 ). In four numbers (nos. 2, 3, 4, 5) two oboes replace the two clarinets, in no. 2 the horns are omitted and in no. 19, the bassoons. Numbers of players on the string parts are not indicated, but sets of parts for later vaudevilles in another Moscow archive ${ }^{27}$ suggest that it was common to have 4-6 first violins, 4 seconds, and

25 The Russian usage of patronymics and diminutives is explained in Longley $(2000,411)$.

26 Here I follow the order of parts as written in the score, top to bottom.

27The Glinka Museum Archive has duplicates of some of the Verstovsky vaudevilles in the Moscow Conservatory Library, both scores and parts. For a vaudeville called Tsiganka there are two copies each of 
1 or 2 violas. "Basso" refers to cellos and double bass(es) together; only occasionally are parts marked specifically for one or the other included in the sets of parts. At the most, then, this was a small orchestra of perhaps eight woodwind players, some of whom could double on the remaining two wind parts, twelve to fourteen strings, and no brass or percussion. It must be kept in mind, however, that the score does not reflect variations in orchestration for a theatrical work, and that some performances may have had additional instrumental parts added.

Table 2. Instrumentation for two vaudevilles in St. Petersburg, circa 1820

\begin{tabular}{|c|c|c|c|c|c|c|c|}
\hline & Hn. & Fl. & Ob. & Cl. & Bsn. & Strings & $\begin{array}{l}\text { Brass \& } \\
\text { Perc. }\end{array}$ \\
\hline $\begin{array}{l}\text { Babushkin y } \\
\text { Popugai } \\
\text { No. } 1\end{array}$ & 2 in $D$ & 2 & & 2 in $A$ & 2 & $\begin{array}{l}\text { Vln. I \& } \\
\text { II, Vla., } \\
\text { Basso }\end{array}$ & \\
\hline No. 2 & & 1 & 2 & & 2 & Same & \\
\hline Nos. $3,4,5$ & 2 in G & 2 & & & & Same & \\
\hline Nos. $6,9,10$ & 2 in $B$ & 2 & & 2 in $B$ & & Same & \\
\hline Nos. 7, 8, 17 & 2 in $A$ & 2 & & 2 in $A$ & & Same & \\
\hline Nos. 11,12 & 2 in $D$ & 2 & & 2 in $A$ & & Same & \\
\hline No. 13 & 2 in $E$ & 2 & & 2 in $B$ & & Same & \\
\hline No. 14 & 2 in $E$ & 2 & & 2 in $C$ & & Same & \\
\hline No. 15 & 2 in $F$ & 2 & & 2 in $C$ & & Same & \\
\hline Nos. 16,18 & 2 in $C$ & 2 & & 2 in $C$ & & Same & \\
\hline No. 19 & 2 in D & 2 & 2 & 2 in $A$ & & Same & \\
\hline $\begin{array}{l}\text { Novaia } \\
\text { Shalost } \\
\text { No. 4, Solo } \\
\text { \& Chorus }\end{array}$ & 2 in $A$ & 2 & 1 & 2 & 2 & Same & $\begin{array}{l}2 \text { Trp. in } \\
\text { A \& } \\
\text { Timp. in } \\
\text { A \& E }\end{array}$ \\
\hline
\end{tabular}

the first and second violin parts, one of the viola part, and two of the "basso." Roslavlev has the same for the violins and viola, but a single copy for the cello and another for the double bass. A second complete set of parts for Roslavlev provides three copies of the first violin, two of the second, one viola, and two for the cello and double bass (which sometimes play separate lines.) The vaudeville Utro posle bala, probably because it contains a melodrama, has a larger string section: three copies of the part for Violin I, four of Violin II, two of viola, and three of "basso." In each case one or two players may have used each copy. 
We must turn to another of Verstovsky's early vaudevilles to see his idea of orchestration suitable for a larger vocal group, such as a number with chorus. Novaia Shalost [A New Prank], another Khmelnitsky translation first performed at the St. Petersburg Bolshoi just three years later, shows a similar pattern of instrumental accompaniment for most of its numbers. A number for solo and chorus in "Tempo di Marcia," however, is given in addition two trumpets and timpani, perhaps to match the larger vocal group as well as express a martial character.

Table 3. Comparison of orchestra (numbers of string players estimated) for Babushkiny Popugai (1819) with the Théâtre des Variétés (from Almanach des spectacles, 1822). Numbers in parentheses indicate instruments doubled by other players.

\begin{tabular}{|l|l|l|l|l|l|l|l|l|l|l|l|}
\hline & Vln. I & Vln. II & Vla. & Vcl. & D.Bs. & Fl. & Ob. & Cl. & Bsn. & Hn. & Trb. \\
\hline \hline $\begin{array}{l}\text { Babushkiny } \\
\text { Popugai }\end{array}$ & $4-6$ & 4 & 2 & 2 & 1 & 2 & 2 & $(2)$ & 2 & 2 & \\
\hline $\begin{array}{l}\text { Théâtre des } \\
\text { Variétés }\end{array}$ & 4 & 5 & 2 & 3 & 2 & 1 & & 2 & 1 & 2 & 1 \\
\hline
\end{tabular}

The instrumentation used for Babushkiny popugai matches almost exactly the instrumental forces available at the Théatre des Variétés at this time (table 3). According to the Almanach des spectacles for 1822, the musicians on hire consisted of a "chef," four first violins, five seconds, three basses (cellos), two double basses, two "quintes" (violas), two horns, two clarinets, and one each of flute, bassoon, trombone, and "accordeur." This group is also similar to that outlined by Charlton $(1985,94-100)$ for the Comédie-Italienne in the years 1760-62: four first violins, four seconds, two violas, three cellos, one double bass, two oboes/flutes, no clarinets, two bassoons, two horns, and a violinist who doubled on timpani. ${ }^{28}$ The Comédie-Italienne was not, however, restricted to these instruments:

The "regular" ensemble instruments were by no means the only ones heard at the Comédie-Italienne. The Registres reveal an unexpected number of references to instruments such as the harp, viola d'amore and so on, and to groups of military instruments... (Charlton 1985, 95)

Charlton goes on to mention "the 'repeated hiring of two trumpets' for the Comédie Italienne for specific works." The inclusion of trumpets and timpani for the choral number from Novaia shalost, then, might indeed reflect the Variété's performance of the vaudeville finale with chorus in Les perroquets de la mère Philippe, even though it involves instruments not mentioned in the

28 "... the Comédie-Italienne, to the end of the century, almost never paid an individual exclusively as a timpanist; the job was doubled with a violinist or violist." (Charlton 1985, 94). 
theatre's roster of 1822. Like the Comédie-Italienne in the 1760s, the Variétés in 1818 may have hired instruments especially for a particular performance or had players who could double on the needed parts. ${ }^{29}$ Since the orchestra specified by Verstovsky for Babushkiny Popugai matches the orchestral roster for the theatre in which Les perroquets de la mère Philippe was performed, it seems likely that the Russian composer was emulating French orchestral practice for vaudevilles. This, in turn, suggests that the choice of instrumentation for the various kinds of musical numbers in Babushkiny popugai might also reflect Parisian practice.

Some aspects of Verstovsky's orchestral settings of numbers can be seen in the modern piano-vocal score of Kto brat, kto sestra. Here we present the opening of two contrasting numbers published in Verstovsky and Pisarev's own collection, Dramaticheskii Albom Liubitelei Teatra i Muzyki [Dramatic Album for Lovers of Theatre and Music] (Moscow: K. Ventsel, 1826). Examples 3a and 3b illustrate the opening measures of two numbers from the opera-vaudevilles, Uchitel' $i$ Uchenik [Teacher and Pupil] (Moscow, 1824) and Vstrecha dilizhansov [A Meeting of Coaches] (Moscow, 1825). They illustrate, in numbers of different character, his usual orchestral introduction, sometimes with melodic allusions to the vocal part. Once the vocal part enters, however, the accompaniment settles into a simple chordal background with snippets of instrumental interjections between phrases. Sometimes there is some instrumental support for the vocal line, with flute or perhaps viola doubling. For duos or trios, two or more characters may sing in alternation, but very rarely together. Occasionally a more elaborate contrapuntal line is added against the vocal part, presumably when the singer was a strong one.

The orchestra could also provide an inter-textual allusion creating the possibility for irony or humour. An excellent illustration of this is seen in example 4, the orchestral introduction and accompaniment to a duet in Verstovsky's vaudeville Dom sumasshedshikh [The Madhouse] (St. Petersburg, 1822). The two characters involved are the manservant of the main character and his daughter's fiancé. Verstovsky makes a clear allusion here to the overture of a favourite St. Petersburg opera, Mozart's Le nozze di Figaro, whose main character is both a fiancé and manservant. This is a fine indication of the sophistication of the audience, to say nothing of the eclectic origins of Verstovsky's orchestral style. ${ }^{30}$

One major difference between the performance of vaudevilles in Paris and St. Petersburg or Moscow was venue. In general, the Paris theatres specialized

29 The Almanach des spectacles $(1824,122-23)$ shows that the orchestra at the Variétés had increased to include a Chef, Second chef, five first violins, five seconds, three cellos, two double basses, two violas, two horns, two clarinets, one flute, one bassoon and two trombones. The theatre also had a composer and a choral répétiteur/copyist. Orchestras at some other theatres which included vaudevilles in their repertoire were even larger, but this would not necessarily mean that they gave vaudevilles a more elaborate orchestral accompaniment, or that they had given up the practice of doubling. It will be interesting to see if other genres composed by Verstovsky also match the orchestral forces at the original Paris theatre. One can predict that his melodramas would require the larger orchestra resident at the Porte-Saint-Martin.

$30 \mathrm{~A}$ fuller treatment of Verstovsky's orchestration, including a comparison of the vaudevilles, melodramas, and operas with each other and with foreign models will be the subject of a separate article. 

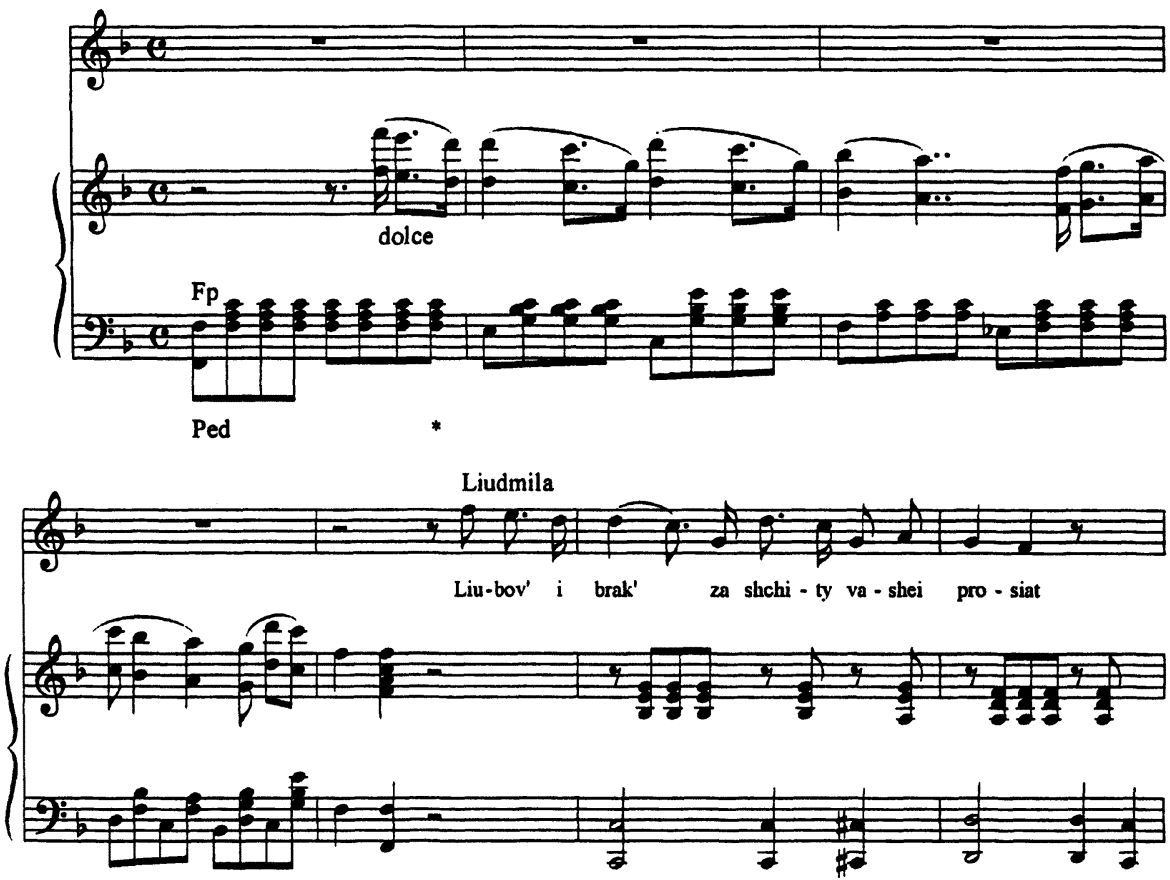

Example 3a: Romance "Liubov' i brak' za shchity vashei prosiat" [Love and Marriage Beg Your Defence] from Verstovsky's opera-vaudeville Uchitel' $i$ Uchenik [Teacher and Pupil], Verstovsky and Pisarev (1825-26, no. 3)

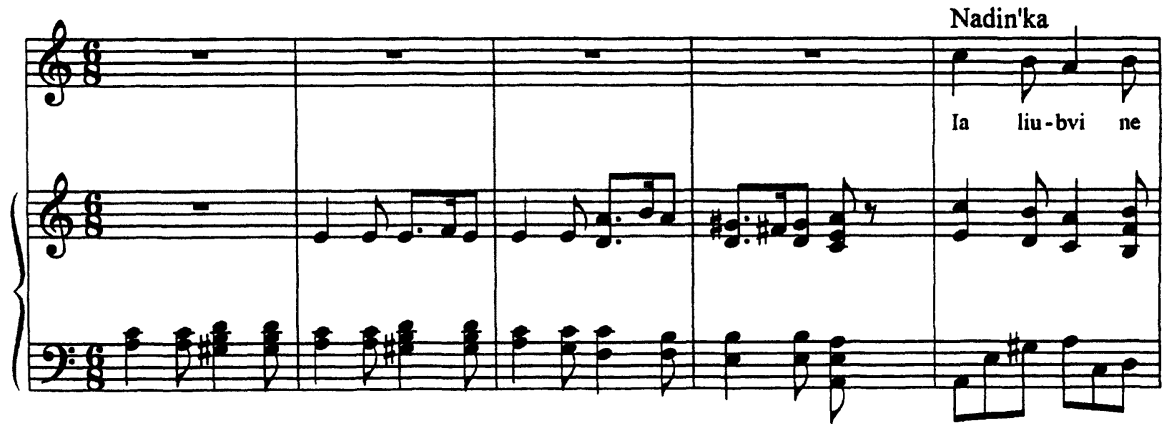

Example 3b: "Ia liubov ne znala prezhde" [I Did Not Know Love Before] from Verstovsky's opera-vaudeville Vstrecha Dilizhansov [A Meeting of Coaches], Verstovsky and Pisarev (1825-26, no. 5) 
Example 3b: cont'd
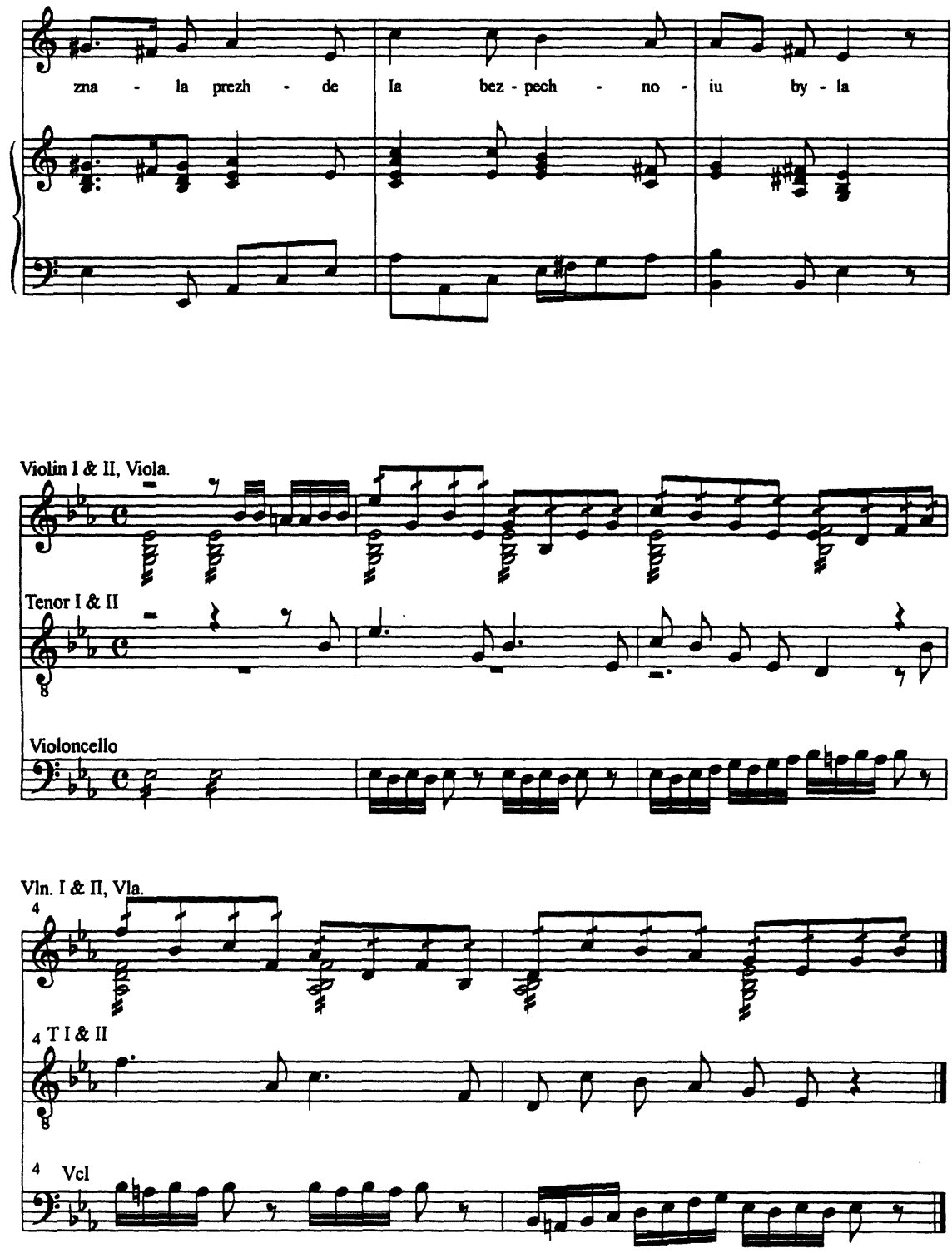

Example 4: Author's arrangement of opening of duet for Eduard \& Zhak from A. N. Verstovky, Dom sumasshedshikh ili Strannaia Svad'ba [The Madhouse or the Strange Wedding] from manuscript Polnoe sobranie muzyki sochineniia A. N. Verstovskogo [Complete collected musical compositions of A. N. Verstovsky], vol. 3, Taneev Library, Moscow Conservatory 
in specific types of representation, with opera at the Opera and vaudeville at the Boulevard theatres. The Théâtre des Variétés, where Les perroquets de la mère Philippe was first performed, was restricted to vaudevilles, parodies and small opéras-comiques. In Russia, at least for the Russian and German troupes, no such segregation pertained, nor were evenings restricted to one or another type of piece, as they were at the Paris Opéra-Comique.

The Imperial Theatres in St. Petersburg for which we have records of repertoire during the eighteen-twenties were the Bolshoi and the Malyi (the familiar Aleksandrinsky, Mikhailovsky and Maryinsky theatres were not yet built) and are usually described as giving separate genres-opera and ballet at the former, spoken and musical plays at the latter. General descriptions like these cover several decades of theatrical activity and so far no-one has given a detailed picture of a season or year at either theatre. For this reason, I am using the French-language newspaper, Le Journal de Saint-Pétersbourg, which began publication in 1825 , as a source for the language and genre of theatrical pieces during this early period. The Journal started publishing announcements of the "Spectacles" to be given at St. Petersburg theatres in 1827 and from this we can see that at that time there were three troupes in the city-the Russian, German and French. ${ }^{31}$ In 1827 the French troupe gave only spoken drama and the lighter musical genres (174 items including repetitions of titles), almost always at the Malyi. The German (100 items) and Russian troupes (about 350), however, performed in both theatres, and the division of genres was not so clear-cut. ${ }^{32}$ For one thing, aside from repertoire in their own language both troupes presented Italian and French works in translation. Secondly, although opera was generally given at the Bolshoi and spoken drama at the Malyi, vaudevilles, opera-vaudevilles, melodrama and small operas might be performed in either theatre, and sometimes a single title appeared in both theatres.

All three troupes frequently gave a mixture of genres during one evening's entertainment, although big-name foreign works, such as Vodovoz [The Watercarrier, Russian name for Cherubini's Les deux journées] often stood alone (according to the newspaper announcements). December, 1827 saw two performances of Cavos's Ivan Susanin, one at the Bolshoi the other at the Malyi, in each case followed by a Russian vaudeville. Any combination seemed possible: spoken drama and vaudeville; comedy in five acts and "grand opera";

31 The musical theatre performances by the French troupe can easily be overlooked, so often is it omitted from discussion. For example, Richard Taruskin $(1997,187)$ states that "Between 1812 and 1829 operas were given in St. Petersburg only in Russian and German." This is misleading, since the French troupe performed the "lesser genres" of opera-comique, vaudeville, opera-vaudeville, melodrama and small operas as well as spoken tragedies and comedies. The troupe had arrived in Russia in 1819 (Keldysh 1986, 4:354-64): "Nachalo spektaklei novoi frants. truppy v S.P. Bolshom teatre" [beginning of performances of a new French troupe at the St. Petersburg Bolshoi (my emphasis)] in 1819. It was still in the capital in 1826, when, by command of Nicholas I, its repertoire was restricted to "comedies and vaudevilles," and in 1827 only two of its performances were at the Bolshoi. The distinction between "high" and "low" genres would be somewhat lessened by the Russian troupe's practice of replacing operatic recitatives with spoken dialogue.

32 All three troupes gave a few performances at the Kamenno-Ostrovsky wooden theatre newly opened in 1827 . 
comic opera in two acts and comedy-vaudeville in one act; spoken tragedy and intermedia-sometimes even three different genres. When we consider that a single Russian singer or actor could frequently be called upon to perform in any one of these genres, it is clear that rigid separation of genres did not pertain in Russia. The necessity of fitting a large and small work together into one evening's entertainment may also explain why a vaudeville might be shorn of several musical numbers. ${ }^{33}$

The implications of this mixture of genres, especially at the Bolshoi, is that the orchestra of the house was not trimmed to the size of any one type of repertoire as it would be at a Boulevard Theatre in Paris. Lists of players would not tell us anything about the orchestration of the lighter works and for the Russian houses it was perhaps not a matter of hiring extra players but of having the appropriate instrumentalists from the opera or ballet orchestra "stay on" for the vaudeville. Availability of instrumentalists, either in kind or in number, would presumably not be a problem.

Accounts of the development of Russian opera often emphasize the prevalence of foreign works on the stages of St. Petersburg and Moscow, to the detriment of Russian music and composers (Seaman 1991, 248). To a certain extent, the French vaudevilles examined here confirm that picture. It should not be overlooked, however, that the existence of translated works also indicates that a Russian-speaking audience was in place by the 1820's-an audience for which twice as many works were provided as for French-speaking audiences. ${ }^{34}$ It is hard to escape the conclusion that the encouragement of a Russian theatre was one of the goals of the Tsar's Directorate of the Imperial Theatres at this time. The autocracy which had been the "vanguard of civilization in Russia" (Malia 1999, 140) could now serve a cultivated Russian society which it itself had created. Put together with the surge of Russian patriotism following the French invasion of Russia in 1812 and the related banishment of a French troupe from St. Petersburg between 1812 and 1819, there were many powerful incentives for the development of Russian theatre during this period.

The vaudeville of Paris-entertainment for a broad audience-was not, in a sense, the vaudeville of Russia, seen on the boards of the spacious and elegant Bolshoi. Although they were hearing and seeing the latest in Western entertainment, this audience was also developing expectations of different performance conditions from what prevailed in the West: a mixture of genres in one evening's entertainment, venues which offered everything from ballet and opera through spoken drama and pantomime, three theatre troupes performing in as many different languages. This richness would be important in the development of a sophisticated audience, the most important precondition for

33I have not been able to discover what other work(s) shared the evening with Babushkiny popugai at its première, but Verstovsky's Novaia shalost, referred to above, was on one occasion in 1822 given after Auguste Kotzebue's drama in five acts, Syn liubvi [Love's Son] in a performance at the St. Petersburg Malyi Theatre. See Svodnyi katalog serialnykh izdanii rossii $(1997,127)$.

34 The aristocracy continued to favour the French troupe in St. Petersburg, all the way to the end of the nineteenth century. See the account on "Les Theâtres Impériaux" [The Imperial Theatres] of Aloys Mooser $(1994,110)$. 
the development of a national art. The easy combination of genres, too, would have its effect in creating the eclecticism that is the precondition of high art.

\section{REFERENCE LIST}

Bernandt, Grigorii Borisovich. 1962. Slovar oper. Moscow: Sov. Kom.

Brazier, Nicholas. 1969. Histoire des petits théâtres de Paris depuis leur origine. 2 vols. New York: Burt Franklin. (Orig. pub. Paris: Allardin, 1838.)

Brown, Bruce Alan. 1992. "La diffusion et l'influence de l'opéra-comique en Europe au XVIII ${ }^{\mathrm{e}}$ siècle." In Vendrix 1992b, 283-343.

- 1997. "Viennese opera buffa and the legacy of French theatre." In Hunter and Webster 1997, 50-81.

Brown, Malcolm Hamrick, and Roland John Wiley, eds. 1985. Slavonic and Western Music: Essays for Gerald Abraham. Ann Arbor: UMI Research Press.

Capelle, Pierre Adolphe. 1816. La clé du Caveau. 2nd ed. Capelle: Paris. (Orig. pub. 1811.)

Charlton, David. 1985. "Orchestra and Chorus at the Comédie-Italienne (Opéra-Comique), 1755-99." In Brown and Wiley 1985, 87-108.

Dictionnaire des littératures de langue française. 1994. Paris: Bordas.

Enciclopedia dello spettacolo. 1962. Roma: Sansoni.

Hunter, Mary, and James Webster, eds. 1997. Opera Buffa in Mozart's Vienna. Cambridge: Cambridge University Press.

Keldysh, Iurii, ed. 1973. Muzykalnaia entsiklopediia. Vol. 1. Moscow: Izdatelstvo "Sovetskaia entsiklopediia."

- 1986. Istoriia Russkoi Muzyki IV. Moscow: "Muzyka."

- 1988. Istoriia Russkoi Muzyki V. Moscow: "Muzyka."

Khmel'nitskii, Nikolai. 1849. Sochineniia Khmel'nitskago [Works of Khmel'nitskii]. St. Petersburg: Tip. Karla Kraiia.

Longley, David. 2000. The Longman Companion to Imperial Russia, 1689-1917. Harlow, Essex: Pearson Education Limited.

Malia, Martin. 1999. Russia Under Western Eyes from the Bronze Horseman to the Lenin Mausoleum. Cambridge, MA: The Belknap Press of Harvard University Press.

Malo, Charles, et François Loéve-Weimars, eds. 1822. Almanach des spectacles. Paris: Janet.

Mooser, Aloys. 1994. Souvenirs: Genève 1886-1896, Saint-Pétersbourg 1896-1909. Genève: Georg.

Ringer, Alexander, ed. 1991. Music and Society: The Early Romantic Era, Between Revolutions 1789 and 1848. Englewood Cliffs, NJ: Prentice Hall.

Robert, Paul. 1981. Dictionnaire alphabétique et analogique de la langue française. Paris: Le Robert. 
Sadie, Stanley, ed. 2001. The New Grove Dictionary of Opera. London: MacMillan.

Seaman, Gerald. 1991. "Moscow and St Petersburg." In Ringer 1991, 236-58. Svodnyi katalog serialnykh izdanii rossii, 1801-1825 [Combined Catalogue of Russian Serial Publications, 1801-1825]. 1997. St. Petersburg: Izdatelstvo Rossiiskoi natsionalnoi biblioteki.

Taruskin, Richard. 1997. Defining Russia Musically. Princeton, NJ: Princeton University Press.

Théaulon de Lambert, Marie-Emmanuel-Guillaume-Marguerite, and Armand \& Achille d'Artois de Bournonville. 1818. Les perroquets de la mère Philippe. Paris: Barba.

Vendrix, Philippe, ed. 1992a. Grétry et l'Europe de l'opéra-comique. Liège: Mardaga.

1992b. L'opéra-comique en France au XVIII siècle. Liège: Mardaga. Verstovsky, Alexei Nikolaevich. 1949. Kto brat, kto sestra, ili Obman za Obmanom [Which the Brother, Which the Sister or Trick upon Trick]. Ed. A. B.Voinova. Moscow: Gos. Muz. Izd.

- 1963. Askol'dova Mogila [Askold's Grave]. Ed. B. Dobrokhotov. Moscow: Gos. Muz. Izd.

Verstovsky, Alexei N., and A. Pisarev. 1825-26. Dramaticheskii Albom' dlia Liubitelei Teatra i Muzyki [Dramatic Album for Lovers of Theatre and Music]. Moscow: Ventsel.

Voinova, A. A. 1971. Romansy, Pesni i Kuplety iz Muzikk Vodeviliam i P'esam dlia Golosa c Forepiano [Romances, Songs and Couplets from Music to Vaudevilles and Plays for Voice and Piano]. Moscow: Izdatel'stvo "Muzyka". 
Appendix 1. Incipits of melodies from Verstovsky, Babushkiny Popugai, excerpted from manuscript Polnoe sobranie muzyki sochineniia A. N. Verstovskogo [Complete Collected Musical Compositions of A. N. Verstovsky], vol. 3, Taneev Library, Moscow Conservatory

1.

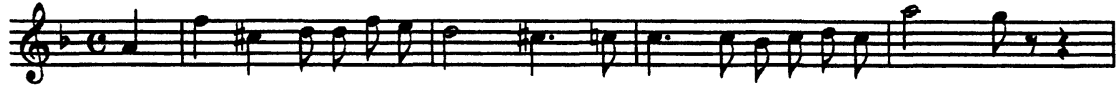

2 .

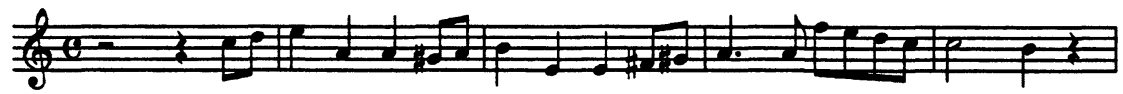

3.

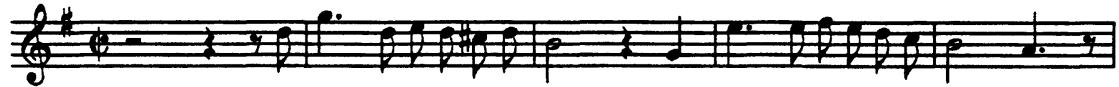

4.

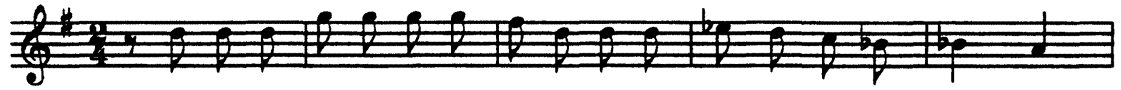

5.

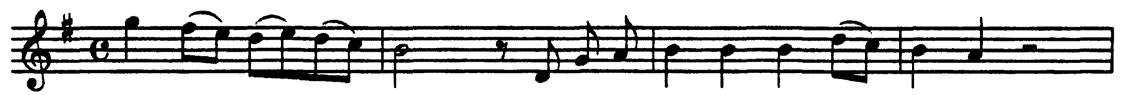

6.

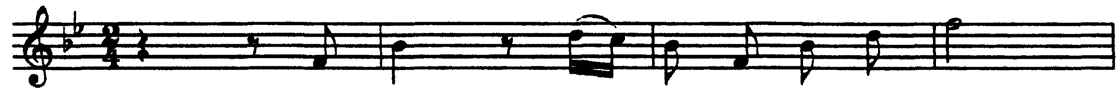

7.

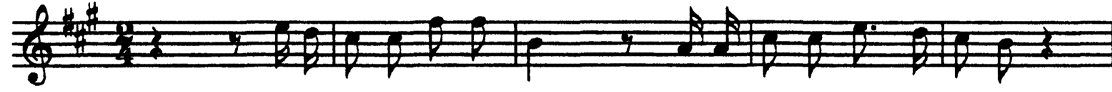

8.

9 \& $\Rightarrow$

10.

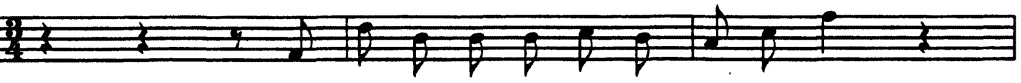


Appendix 2. Melodies from Capelle (1816) used in Les perroquets de la mère Philippe

No. in No. in La clé du Caveau

libretto

No. 366: "Lise épouse l'beau Gernance" ou "L'amour ainsi qu'la nature" [Lisa Marries the Handsome Gernance or Love as well as nature]

1.

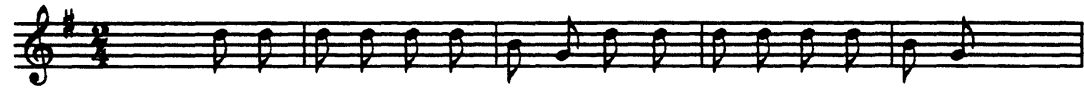

6 No. 823: "Vaudeville de la belle fermière [Vaudeville of the Pretty Farm Wife]

2.

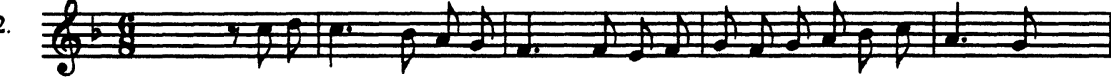

1 No. 352: "Le port Mahon est pris" [Port Mahon is Captured]

4.

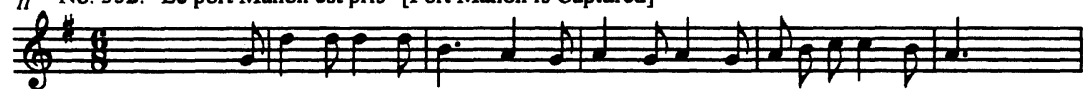

No. 787: "Un esprit présent est un présent de la nature" [A Ready Wit is a Gift of Nature]

"No. 787: "Un esprit présent est un présent de la nature" [A Ready Wit is a Gift of Nature]

22 No. 748: "Mon galoubet" [My Fipple Flute]

9.

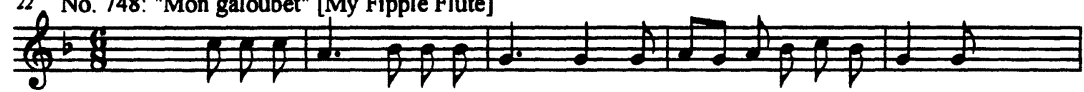

27 No. 1412: "Air de Psyché [Psyche's Tune]

10. 27 .

:
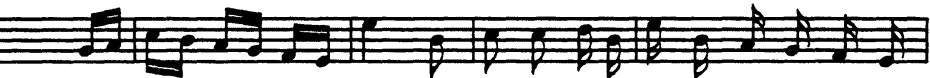

32 No. 1464: "Il me faudra quitter l'empire" [I Will Have to Leave the Empire]

11.

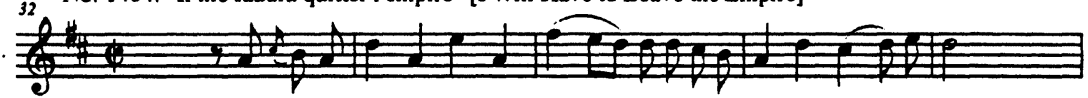

No. 311: "Voulant par ses oeuvres complètes" ou "La résistance inutile" [Striving by all His Deeds or 37 The Useless Resistance]

12.

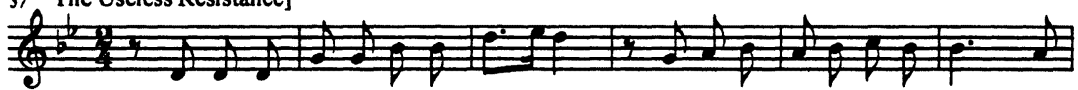

No. 606: "Une fille est un oiseau" [A Girl is Like a Bird]

13. 43

$\exists$

"No. 606: "Une fille est un oiseau" [A Girl is Like a Bird] 


\begin{abstract}
Exceedingly popular in their day, Russian vaudevilles and opera-vaudevilles of the first third of the nineteenth century are not available in modern orchestral scores. Although many of these musical comedies are known to be adapted from French works, for the most part the original French titles are unknown, as are the differences in French and Russian treatments of musical numbers. Focussing primarily on Pisarev's Babushkiny popugai [Grandma's Parrots] (St. Petersburg, 1819), this article compares the original French vaudeville with its Russian adaptation on several points: libretto, performance venues, and musical treatment, the latter based in part on manuscript sources of Alexei N. Verstovsky's orchestral scores.
\end{abstract}

\title{
Résumé
}

Extrêmement populaires à leur époque, les vaudevilles et les opéras-vaudevilles russes du premier tiers du $\mathrm{XIX}^{\mathrm{e}}$ siècle ne se retrouvent pas dans les partitions modernes pour orchestre. Bien qu'il soit notoire qu'un bon nombre de ces comédies musicales soient tirées d'œuvres françaises, on ne connaît pas les titres originaux français, de même qu'on ignore les différences de traitement entre les numéros musicaux français et russes. En s'attardant surtout sur Babushkiny popugai [Les perroquets de grand-mère] de Pisarev (Saint-Pétersbourg, 1819), le présent article compare le vaudeville original français à son adaptation russe sous divers angles : livret, lieux de représentation et traitement musical, celui-ci s'appuyant en partie sur les sources manuscrites des partitions d'Alexeï N. Verstovski. 